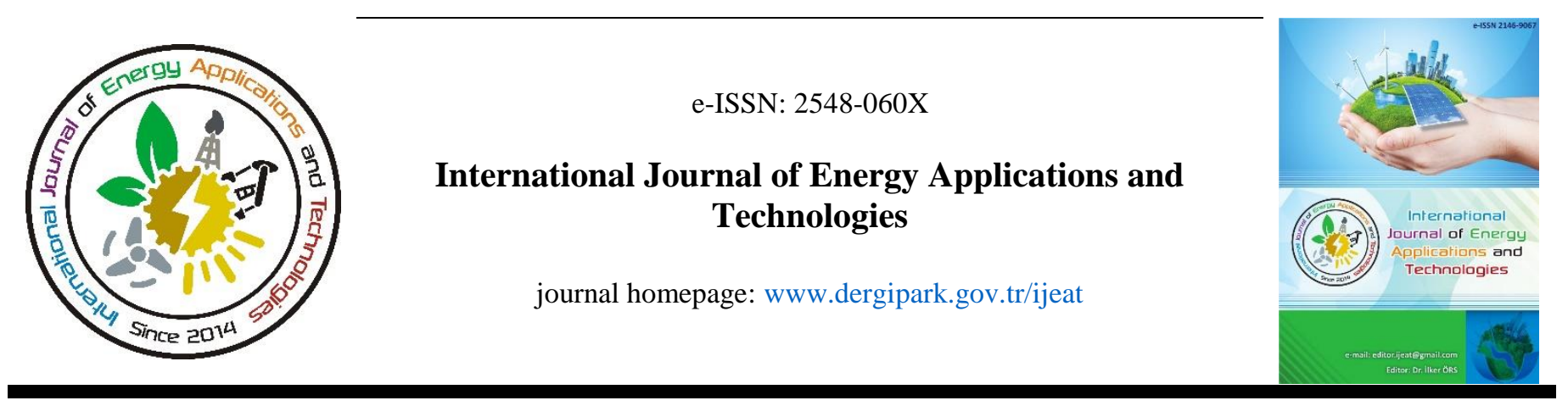

Original Research Article

\title{
Anaerobic co-digestion of food waste, goat and chicken manure for sustainable biogas production
}

Sunil P. Lohani ${ }^{*}$, Ananta Acharya ${ }^{1}$, Robin Koirala ${ }^{1}$, Arpan Koirala ${ }^{1}$, Biplob Lamsal ${ }^{1}$, Sanjay N. Khanal ${ }^{2}$

${ }^{I}$ Department of Mechanical Engineering, Kathmandu University, Dhulikhel, Nepal

${ }^{2}$ School of Environmental Science and Management, Pokhara University, Nepal

\author{
ARTICLE INFO \\ * Corresponding author \\ splohani@ku.edu.np \\ Received June 7, 2020 \\ Accepted October 12, 2020 \\ Published by Editorial Board \\ Members of IJEAT \\ (C) This article is distributed by \\ Turk Journal Park System under \\ the CC 4.0 terms and conditions. \\ doi: 10.31593/ijeat.748982
}

\begin{abstract}
Anaerobic digestion of food waste alone is not very stable due to its acidic nature and high biodegradability. Co-digestion of food waste with alkaline substrate such as chicken manure and goat manure could enhance process stability and biogas yield. In this study comparison of mono digestion of food waste with $8 \%$ total solid content at an ambient temperature and co-digestion of food waste, goat and chicken manure at ratio 5:2:3 and 2:1:1 with $8 \%$ total solid content at an ambient temperature in hilly region of Nepal were carried out. Biogas yield was highest with mixing ratio of 5:2:3 with the values of $109 \mathrm{ml} / \mathrm{gVS}$ followed by mixing ratio of $2: 1: 1$ with the values of $80 \mathrm{ml} / \mathrm{gVS}$. Mono digestion of food waste was not stable and broke down after two weeks of operation. Findings from this study suggests that co-digestion could be a suitable method for addressing the problem related to stability in a single substrate digestion in an ambient temperature condition. Moreover, mixing ratio of co-digestion substrates is important for improved biogas production. Co-digestion of food waste with goat and chicken manure could be a practical approach for sustainable clean energy production and waste management in context of Nepal.
\end{abstract}

Keywords: Anaerobic; Co-digestion; Ambient temperature; Biogas yield; Sustainable

\section{Introduction}

Anaerobic digestion is a series of biological processes that converts complex organic material into methane, carbon dioxide and other byproducts called biogas [1]. Rate of anaerobic digestion is dependent on the environmental conditions, particularly temperature, $\mathrm{pH}$, Carbon-Nitrogen $(\mathrm{C} / \mathrm{N})$ ratio, size and types of substrate, hydraulic retention time (HRT), percentage of inoculum added, essential trace nutrients and toxicants [2]. Biogas has high methane content $(50-75 \%)$, thus can be used as an energy source. The production of biogas from anaerobic digestion has been considered as one of the most energy-efficient and environmentally beneficial technology for bioenergy production [3]. Anaerobic digestion for treating organic waste can reduce waste volume and enrich plant nutrients from residues [1]. Livestock manure, organic municipal waste, kitchen waste and different energy crops are commonly used as substrates to feed anaerobic digesters. These substrates have their own specific character of biodegradability owing to its elemental compositions which affects the whole anaerobic digestion process and thus the gas production [4]. Biomass used as feeding material for biogas production is primarily composed of carbohydrates, proteins, fats, cellulose and hemicellulose. Variation in these compounds in feedstock creates a significant impact on production of biogas [5]. To optimize methane potential, it is important to understand the biogas production potential from different substrates [6]. Anaerobic digestion of single substrates (mono digestion) can cause several problems due 
to their specific inherent properties [7]. Food Waste (FW) having high methane generation potential, faces inhibition such as nutrient imbalance, accumulation of volatile fatty acid, process instability, low buffer capacity [8] and chicken manure $(\mathrm{CM})$ are reported to have low biogas production as well due to high nitrogen concentration [9].

Co-digestion produces positive synergetic effect on account of supply of nutrients which may be deficient in mono digestion and hence improves system stability and methane yield. For instance, mixing substrates with different characteristics can result in the production of optimal $\mathrm{C} / \mathrm{N}$ ratio, $\mathrm{pH}$ and availability of essential trace nutrients. Codigestion with manure helps overcome the anaerobic digestion process problems since manure has high water content and provides necessary nutrients required for the digestion process [10]. With increasing biodegradable content for digestion and diluting the toxic content, codigestion process provides further advantages of adjusting moisture and $\mathrm{pH}$, enlarging the range of bacterial strains being involved in process [11]. Food waste, having high organic content also has high nutrients for microbes [12]. Thus food waste is a preferred material for co-digestion since it improves process stability along with methane production [13].

Additionally, co-digestion may improve the process kinetics rather than the bioavailability of the feedstock. In a study where hydrolysis rates were measured using bio-methane potential (BMP) assays, it was found that co-digested substrates of food wastes and manure showed an increase in hydrolysis rate relative to mono-digestion [14]. Co-digestion of FW with other appropriate substrates could improve the overall methane yield owing to synergistic effects of microorganisms [15], improved nutrients balance, the dilution of potential toxic compounds [16], increased digestion rate and regulation of moisture content [17]. It is very vital to selecting a co-substrate such that it complements the characteristics of all types of waste being used for the codigestion process. Furthermore, problems related to Volatile Fatty Acids (VFA) accumulation and high ammonia concentration could also be addressed through successful codigestion process [18].

Through co-digestion, the advantage of maintained process condition for anaerobic digestion of organic waste is obtained [19]. Studies show that the addition of FW for co-digestion is beneficial for improved methane yield [20]. Co-digestion of food waste with manure up to $60 \%$ of the initial volatile solids (VS) significantly increase the methane yield at mesophilic condition in 20 days HRT [21]. Co-digestion of solid kitchen waste with chicken manure increased biogas production while increasing the solid content to solid to water ratio $1: 1$ and then starts decreasing the biogas production [22].
This paper intends to contribute to the literature in two ways. Firstly, there has been limited study on biogas production involving FW, Goat Manure (GM) and CM as three co-mixed substrates at an ambient condition. Despite multiple studies about co-mixed substrates available in literature, using new co-mixed substrates to study their collective energy production capacity could add new knowledge in the field of biogas. Secondly, household anaerobic digesters in low income countries like Nepal (already installed about 430,000 units of household biogas plants of size $4 \mathrm{~m}^{3}$ to $10 \mathrm{~m}^{3}$ ) operate under ambient environmental condition and hence it is important to understand the performance of digester under different ambient environmental condition. However, almost all studies are available in literature are under temperature controlled conditions and hardly any literature available in an ambient conditions, this study differs from other study mainly because it intends to mimic laboratory experiment close to field household biodigester used in developing countries and help design and relatively accurate prediction of biogas production potential in such conditions. This paper will contribute to increase knowledge on waste management through biogas production in a resource efficient society.

\section{Methodology}

Several experiments were carried out at ambient conditions in lab scale batch and semi-continuous process. Few codigestion mixtures were selected for this experiment to identify optimum co-digestion feeding ratio. Moreover, experiments were carried out at both mono digestion of FW and co-digestion of FW, GM and CM to evaluate the effect on anaerobic digestion operating at ambient condition.

\subsection{Experimental design and digester setup}

Experiments were conducted using three different organic wastes; FW, GM and CM. It was conducted in batch and semi-continuous mode of operation as mono digestion of FW and co-digestion of FW, GM and CM. In the batch reactor, there were different sets of experiments carried out with three different compositions of feeding materials. The batch experiment was labelled as "B" and the details of the different samples composition ratio were shown in Tab.1. The semi-continuous experiment was labelled as " $\mathrm{C}$ " and the details of the samples composition ratio were shown in Tab.1.

Table 1. Feeding material composition ratio, feeding type and sample name

\begin{tabular}{clcc}
\hline S.No. & Experiments & Ratio & Remarks \\
\hline $\mathbf{1}$ & $\begin{array}{l}\text { Food waste with } \\
\text { Inoculum }\end{array}$ & $\begin{array}{c}10 \% \\
\text { (inoculum) }\end{array}$ & Batch \\
$\mathbf{2}$ & $\begin{array}{l}\text { Food waste, goat and } \\
\text { chicken manure }\end{array}$ & $50: 25: 25$ & Batch \\
$\mathbf{3}$ & $\begin{array}{l}\text { Food waste, goat and } \\
\text { chicken manure }\end{array}$ & $50: 20: 30$ & Batch \\
$\mathbf{4}$ & $\begin{array}{l}\text { Food waste, goat and } \\
\text { chicken manure }\end{array}$ & $50: 25: 25$ & $\begin{array}{c}\text { Semi- } \\
\text { continuous }\end{array}$ \\
\hline
\end{tabular}


Feeding materials were selected mainly based on the local resources that were easily available in the vicinity of the Kathmandu University (KU) as well as common waste material in many parts of the country. Fresh cow dung, goat and poultry droppings were collected from Dhulikhel, farm located outside the premises of KU. FW was obtained from canteen of the University. It was mainly composed of cooked rice $(60 \%)$, lentils $(20 \%)$, vegetable peels, raw and cooked vegetables (20\%). The main physio-chemical characteristics for instance total solid (TS), volatile solid (VS), $\mathrm{pH}$ and carbon nitrogen ratio ( $\mathrm{C} / \mathrm{N}$ ratio) of the feeding material and inoculum were measured and shown in Table 2. Feeding samples were stored at $4{ }^{\circ} \mathrm{C}$ and used until 5 days then again new samples were prepared and stored maximum of five days.

Table 2. Feeding material and inoculum characteristics

\begin{tabular}{clcccc}
\hline S. No & Substrate & TS & VS & pH & C/N ratio \\
\hline $\mathbf{1}$ & Inoculum & 6 & 64 & 6.3 & 24 \\
$\mathbf{2}$ & Food & 21.6 & 81.9 & 5.1 & 22 \\
$\mathbf{3}$ & Chicken manure & 47.3 & 68 & 8.1 & 18 \\
$\mathbf{4}$ & Goat manure & 31.7 & 95.6 & 6.8 & 19 \\
\hline
\end{tabular}

In order to evaluate the biogas production potential from mono digestion of FW and co-digestion of FW, GM and CM, batch and semi-continuous process was used under ambient conditions and comparison were made with obtained findings. In the batch process $500 \mathrm{ml}$ reactor was used with fitted infusion sets for gas measurement as shown in Figure 1. All the components were sealed to make airtight setup for $\mathrm{AD}$ process. Each test were carried out in duplicate.

Batch sets of experiments were started with mono digestion of $100 \mathrm{~g}$ of food waste and co-digestion of FW, GM and CM (total $100 \mathrm{~g}$ ) at a mixing ratios of 2:1:1 and 5:2:3. Mixing ratios were chosen arbitrarily to maintain $\mathrm{C}: \mathrm{N}$ ratio and $\mathrm{pH}$ within the acceptable range for anaerobic digestion process. While for the semi-continuous process $5 \mathrm{~L}$ bottles were used with fitted infusion sets for gas measurement. PVC pipes fitted with plastic funnel were used as the inlet for the substrate as shown in Figure 1. All the components were sealed to make airtight setup for $\mathrm{AD}$ process as shown in Figure 1. Each test were carried out in duplicate. Both batch and semi-continuous process set ups were attached to conical flask containing $\mathrm{NaOH}$ solution of 1 mole concentration to absorb $\mathrm{CO}_{2}$ before measurement of the gas. Semi-continuous set of experiment was started with co-substrate of FW: GM: CM with mixing ratio of 2:1:1. The loading rate and hydraulic retention time (HRT) of the semi-continuous process was $1.7 \mathrm{gVS} / \mathrm{l} . \mathrm{d}$ and $40 \mathrm{~d}$, respectively. The semicontinuous digester was operated about 85 days where after 70 days steady state condition was achieved.

All reactors were prepared in duplicate and the average measurements were used for the analysis. Experiments were carried out at an ambient condition of room temperature that is average temperature of $18-25{ }^{\circ} \mathrm{C}$. In both batch and semi- continuous sets of experiments 10\% inoculums were added. The daily biogas production and ambient temperature were recorded throughout the experiment.

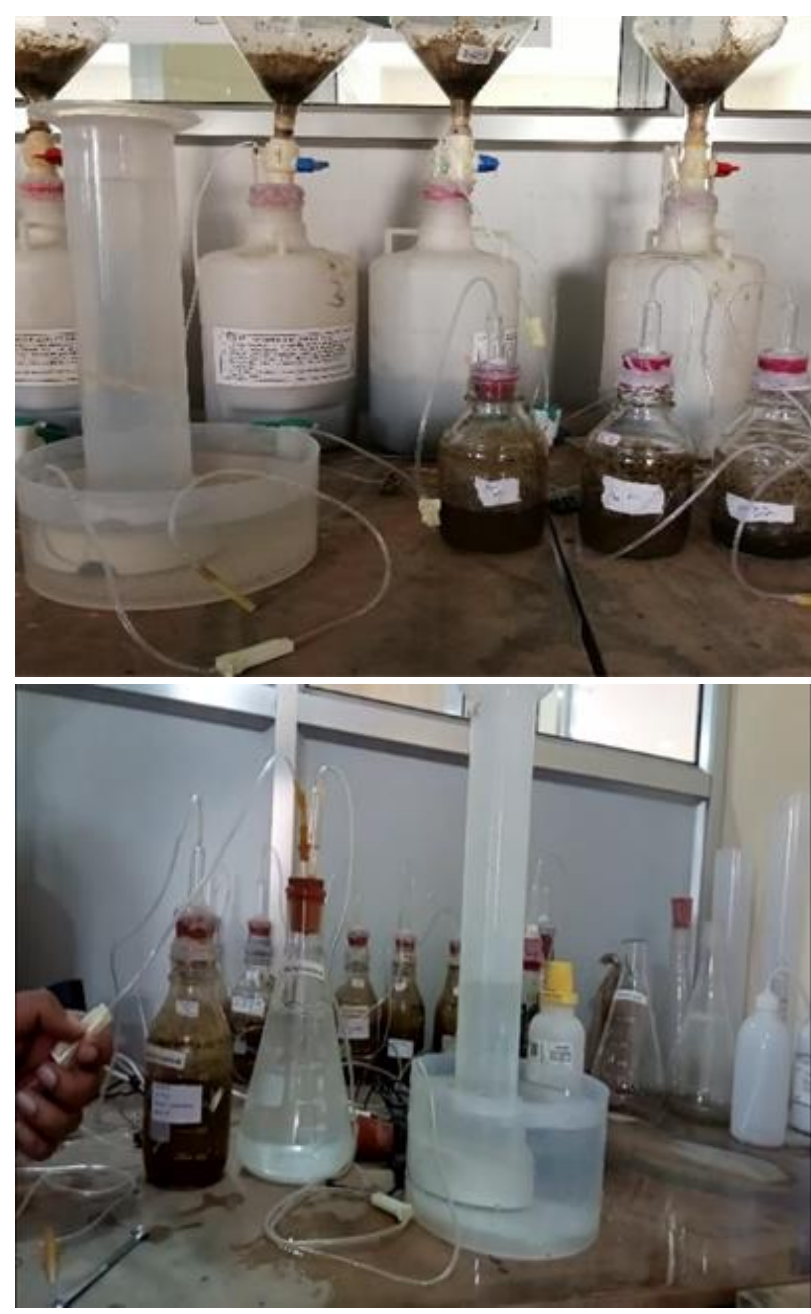

Fig.1. Laboratory set ups of the batch and semi-continuous process

\section{Results and Discussion}

The experiment results were obtained for a period of month from batch reactor. Figure 2 shows the daily and cumulative biogas production from the tests conducted in batch reactor. Mono digestion of food waste was not stable and broke down after two weeks of operation as shown in Figure 2. Biogas yield of mono digestion of food waste was $11.2 \mathrm{ml} / \mathrm{gVS}$ which is very low. Lower methane yield could be due to high biodegradability of $\mathrm{FW}$ which causes problems in the progress of the digestion process because the production of VFA was faster than their conversion into methane [22]. As a result, the $\mathrm{pH}$ got reduced to a range of 4-5 which eventually slower down the gas production.

Co-digestion of food waste, goat and chicken manure at a ratio of 2:1:1 seems higher during the initial period than that of the biogas production from the co-digestion of food waste, goat and chicken manure at a ratio of 5:2:3 as shown in Figure 2. However, after two weeks of operation biogas production is higher at the ratio of 5:2:3. In the first set up at 
the ratio $2: 1: 1$ biogas yield obtained was $78 \mathrm{ml} / \mathrm{gVS}$ whereas in the second set up at the ratio 5:2:3 biogas yield obtained was $109 \mathrm{ml} / \mathrm{gVS}$. This could be due to changes in the ratio of food waste, goat and chicken manure in two different set ups. The slight increase in the amount of poultry manure in the latter set up could have positive effect to neutralize $\mathrm{pH}$, ammonia content and nutrients that could be the reason for producing higher gas after few days of operation [23]. In the first set up the gas production was lesser and this may be due to drop in $\mathrm{pH}$ during anaerobic digestion process as measured pH 5.8 after the experiment and that could be due to accumulation of VFA [24].

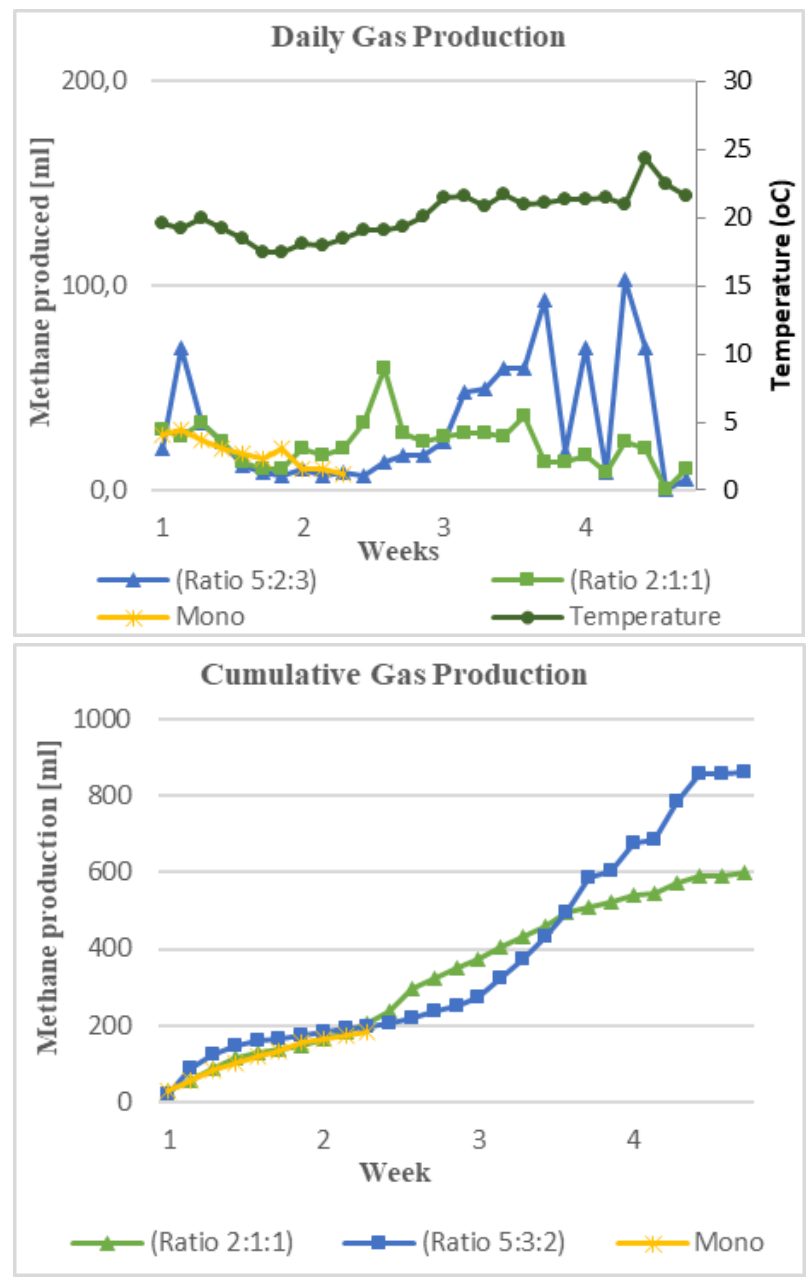

Fig.2. Daily and cumulative biogas production at batch reactor

Figure 3 shows the daily and cumulative biogas production from co-digestion of food waste, goat and chicken manure at ratio 2:1:1 in the semi-continuous feeding process. Biogas yield obtained in this process was $80 \mathrm{ml} / \mathrm{gVS}$, which is similar to that obtained in batch process for the same ratio. The co-digestion process containing goat and chicken manure has a sufficient buffer capacity. Goat and chicken manure contains ammonia and enzymes that helps buffer the higher biodegdrability and acidic nature of food waste and enhance biogas production. The figure 2 and 3 shows the gas production rate is higher for co-digestion.

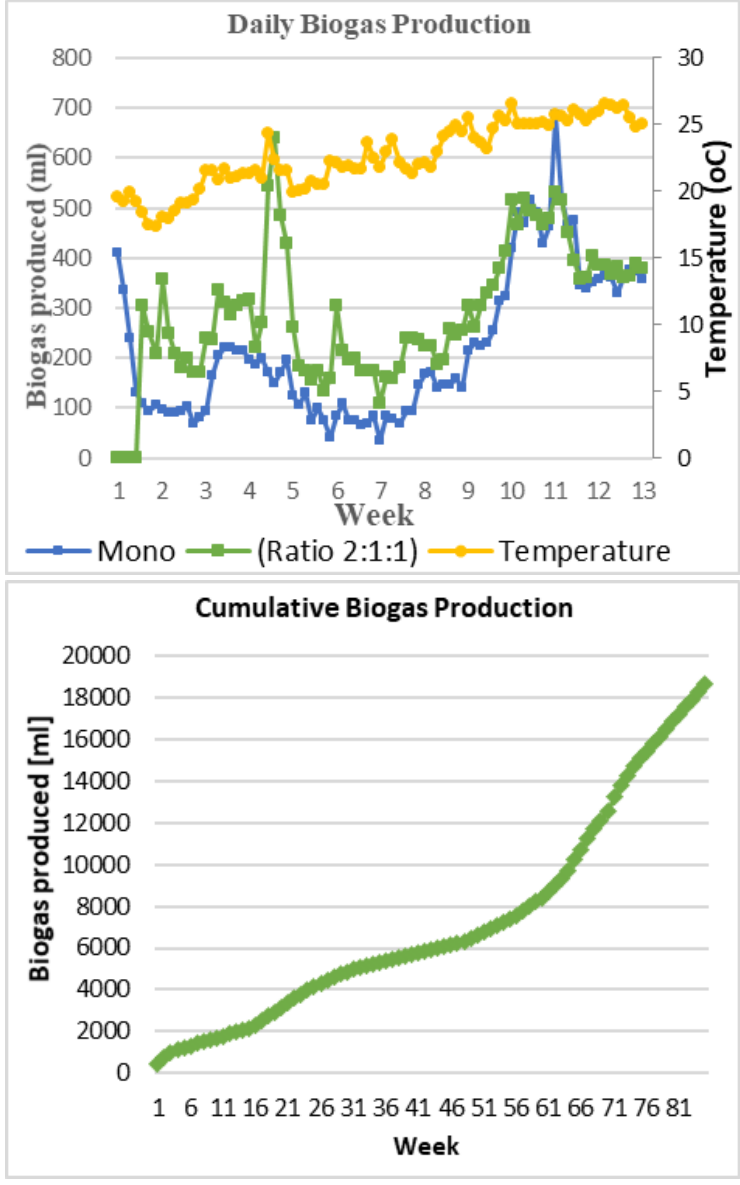

Fig.3. Daily and cumulative biogas production at semi-continuous reactor

\section{Comparison with other studies}

Most of the operational parameters of this study are nearly similar to that of several other studies except operational temperature as shown in table 3 . This study was carried out under ambient temperature condition that is without any temperature control, which was basically the case of household biodigester operated in low income countries like Nepal. However, almost all studies available in the literature are conducted at temperature controlled conditions either it be psychrophilic, mesophilic or thermophilic.

The major difference of this study was the uncontrolled ambient temperature and co-substrate of feeding materials. In this study co-digestion of food waste, goat and chicken manure were carried out at ambient temperature of laboratory room, however, there are no literature found with the codigestion of these three materials. The biogas yield at ambient temperature and the controlled mesophilic temperature shows significant variation in biogas yield as shown in Table 3. Ambient condition digestion process produce almost one fourth to one sixth of biogas yield than that of controlled mesophilic condition for nearly similar operational conditions. This shows household level biogas plant where controlled temperature is not possible must be careful in selecting feeding materials as well as biogas production estimation from their organic waste. 
Table 3. Comparison of this result with others result

\begin{tabular}{|c|c|c|c|c|c|c|c|}
\hline $\begin{array}{c}\text { Reactor } \\
\text { Type }\end{array}$ & Feeding Material & $\begin{array}{c}\text { Feeding } \\
\text { Ratio }\end{array}$ & $\begin{array}{c}\text { HRT } \\
\text { (days) }\end{array}$ & $\begin{array}{c}\text { OLR } \\
\text { (gVS/l.d) }\end{array}$ & $\begin{array}{c}\text { Average } \\
\text { Temperature }\left({ }^{\circ} \mathrm{C}\right)\end{array}$ & Biogas Yield & Reference \\
\hline Batch & Food waste & - & 30 & - & $18-25$ & $11.2 \mathrm{~L} / \mathrm{kgVS}$ & \multirow{5}{*}{ This Study } \\
\hline Batch & $\begin{array}{c}\text { Food waste, goat } \\
\& \text { poultry }\end{array}$ & $50: 25: 25$ & 30 & - & $18-25$ & $78 \mathrm{~L} / \mathrm{kgVS}$ & \\
\hline Batch & $\begin{array}{c}\text { Food waste, goat } \\
\& \text { poultry }\end{array}$ & $50: 20: 30$ & 30 & - & $18-25$ & $109 \mathrm{~L} / \mathrm{kgVS}$ & \\
\hline $\begin{array}{c}\text { Semi- } \\
\text { continuous }\end{array}$ & Food waste & - & 40 & 1.7 & $18-25$ & $72 \mathrm{~L} / \mathrm{kgVS}$ & \\
\hline $\begin{array}{c}\text { Semi- } \\
\text { continuous }\end{array}$ & $\begin{array}{l}\text { Food waste, goat } \\
\text { \& poultry }\end{array}$ & $50: 20: 30$ & 40 & 1.7 & & $80 \mathrm{~L} / \mathrm{kgVS}$ & \\
\hline Batch & Food waste & - & 30 & - & $35^{\circ} \mathrm{C}$ & $657 \mathrm{~L} / \mathrm{kgVS}$ & [26] \\
\hline Batch & $\begin{array}{l}\text { Food waste \& } \\
\text { dairy manure }\end{array}$ & $32: 68$ & 30 & - & $35^{\circ} \mathrm{C}$ & $455 \mathrm{~L} / \mathrm{kgVS}$ & [26] \\
\hline Batch & $\begin{array}{l}\text { Food waste: dairy } \\
\text { manure }\end{array}$ & $40: 52$ & 30 & - & $35^{\circ} \mathrm{C}$ & $531 \mathrm{~L} / \mathrm{kgVS}$ & [26] \\
\hline $\begin{array}{c}\text { Semi- } \\
\text { continuous }\end{array}$ & $\begin{array}{l}\text { Food waste: cow } \\
\text { manure }\end{array}$ & $60: 40$ & 20 & $3 \mathrm{~g} \mathrm{VS} / \mathrm{L} / \mathrm{d}$ & $37^{\circ} \mathrm{C}$ & $\begin{array}{c}430 \pm 28 \mathrm{ml} / \mathrm{g} \\
\text { VS }\end{array}$ & [27] \\
\hline $\begin{array}{c}\text { Semi- } \\
\text { continuous }\end{array}$ & Food waste & - & 20 & $4.79 \mathrm{~g} \mathrm{VS} / \mathrm{L} / \mathrm{d}$ & $37^{\circ} \mathrm{C}$ & $358 \mathrm{ml} / \mathrm{g}$ VS & [28] \\
\hline $\begin{array}{c}\text { Semi- } \\
\text { continuous }\end{array}$ & $\begin{array}{c}\text { Piggery } \\
\text { wastewater: Food } \\
\text { waste }\end{array}$ & 7:93 & 20 & $4.86 \mathrm{~g} \mathrm{VS} / \mathrm{L} / \mathrm{d}$ & $37^{\circ} \mathrm{C}$ & $388 \mathrm{ml} / \mathrm{g} \mathrm{VS}$ & [28] \\
\hline $\begin{array}{c}\text { Semi- } \\
\text { continuous }\end{array}$ & $\begin{array}{c}\text { Piggery } \\
\text { wastewater: Food } \\
\text { waste }\end{array}$ & $17: 83$ & 20 & $4.36 \mathrm{~g} \mathrm{VS} / \mathrm{L} / \mathrm{d}$ & $37^{\circ} \mathrm{C}$ & $479.5 \mathrm{ml} / \mathrm{g} \mathrm{VS}$ & [28] \\
\hline $\begin{array}{c}\text { Semi- } \\
\text { continuous }\end{array}$ & $\begin{array}{l}\text { Cafeteria food } \\
\text { waste }\end{array}$ & - & 30 & $2.8 \mathrm{~g} \mathrm{VS} / \mathrm{L} / \mathrm{d}$ & $37 \pm 2^{\circ} \mathrm{C}$ & $363 \pm 4 \mathrm{ml} / \mathrm{g}$ VS & [29] \\
\hline $\begin{array}{c}\text { Semi- } \\
\text { continuous }\end{array}$ & $\begin{array}{c}\text { Cafeteria food } \\
\text { waste: cow } \\
\text { manure }\end{array}$ & $30: 70$ & 30 & $4.4 \mathrm{~g} \mathrm{VS} / \mathrm{L} / \mathrm{d}$ & $37 \pm 2^{\circ} \mathrm{C}$ & $\begin{array}{c}372 \pm 41 \mathrm{ml} / \mathrm{g} \\
\mathrm{VS}\end{array}$ & [29] \\
\hline
\end{tabular}

\section{Conclusions}

This study compared the methane production from food waste only and co-digestion of food waste, goat and poultry manure for two different ratios under ambient temperature conditions and the experiment was carried out at batch and semi continuous processes. The 5:2:3 mixture of food waste, goat and chicken manure had the highest biogas yield of 109 $\mathrm{ml} / \mathrm{gVS}$. Co-digestion seem to have highest biogas yield as well as process stability than mono digestion of food waste, which saw process failure after two weeks of operation. This experimental results would help in demonstrating the difference in biogas yield between mono digestion of food waste and co-digestion of FW, GM and CM at ambient conditions. Moreover, it helps understand the adverse effects on biogas yield under ambient temperature, which leads to improve estimation of biogas production in such conditions. Findings from this study and other literatures suggests that further investigations on the use of indigenous insulating techniques to anaerobic digesters operating at ambient conditions would be essential which would potentially stabilize the fluctuating ambient temperatures and increase the biogas yield. This kind of study is important to demonstrate how best the available resources can be utilized and could be an option for sustainable organic waste management even in low income countries.

\section{Acknowledgment}

The authors would like to acknowledge university grant commission Nepal for the financial support (FRG-73/74ENGG-02).

\section{ORCID}

Sunil P. Lohani Sanjay N. Khanal

$0000-0001-6689-392 X$ 0000-0001-9265-7293

\section{References}

[1] Mata-Alvarez, J., Macé, S. and Llabrés, P. 2000. Anaerobic digestion of organic solid wastes. An overview of research achievements and perspectives. Bioresource Technology, 74(1), 3-16.

[2] Lohani, S. P. and Havukainen, J. Anaerobic Digestion: Factors Affecting Anaerobic Digestion Process, in: Varjani, S., Gnansounou, E., Gurunathan, B., Pant, D., Zakaria, Z., Waste Bioremediation, Energy, Environment, and Sustainability, Springer, Singapore, 2018, 343-359.

[3] Weiland, P. 2010. Biogas production: current state and perspectives. Applied Microbiology and Biotechnology, 85(4), 849-60.

[4] Lesteur, M., Bellon-Maurel, V., Gonzalez, X., Latrille, E., Roger, J. M., Junqua, G. and Steyer, J. P. 2010. Alternative methods for determining anaerobic 
biodegradability: A review. Process Biochemistry, 45(4), 431-440.

[5] Jingura, R.M. and Kamusoko, R. 2017. Methods for determination of bio methane potential of feedstock's: a review. Biofuel Research Journal, 4(2), 573-586.

[6] Lohani, S.P. 2020. Anaerobic Co-digestion of Food Waste with Cow Manure. Iranian Journal of Energy and Environment, 11(1), 57-60.

[7] Cardona, L., Levrard, C., Guenne, A, Chapleur, O. and Mazéas, L. 2019. Co-digestion of wastewater sludge: Choosing the optimal blend. Waste Management, 87 , 772-781.

[8] Mehariya, S., Patel, A. K., Obulisamy, P. K., Punniyakottia, E. and Wong, J. W. C. 2018. Co-digestion of food waste and sewage sludge for methane production: Current status and perspective. Bioresource Technology, 265, 519-531.

[9] Demirci, G. G. and Demirer, G. N. 2004. Effect of initial COD concentration, nutrient addition, temperature and microbial acclimation on anaerobic treatability of broiler and cattle manure. Bioresource Technology, 93(2), 109117.

[10] Angelidaki, I., Alves, M., Bolzonella, D., Borzacconi, L., Campos, J. L., Guwy, A. J., Kalyuzhnyi, S., Jenicek, P. and van Lier, J. B. 2009. Defining the biomethane potential (BMP) of solid organic wastes and energy crops: a proposed protocol for batch assays. Water Science and Technology, 59(5), 927-934.

[11] Tchobanoglous, G., Theisen, H. and Vigil, S. Integrated Solid Waste Management, McGraw-Hill Inc, New York, 1993.

[12] Bah, H., Zhang, W., Wu, S., Qi, D., Kizito, S. and Dong, R. 2014. Evaluation of batch anaerobic co digestion of palm pressed fiber and cattle manure under mesophilic conditions. Waste Management, 34, 1984-1991.

[13] Li, Z., Chen, Z., Ye, H., Wang, Y., Luo, W., Chang, J-S. Li, Q. and He, N. 2018. Anaerobic co digestion of sewage sludge and food waste for hydrogen and VFA production with microbial community analysis. Waste Management, 78, 789-799.

[14] Ebner, H. J., Labatut, A. R., Lodge, S. J., Williamson, A. A. and Trabold, A. T. 2016. Anaerobic co-digestion of commercial food waste and dairy manure: Characterizing biochemical parameters and synergistic effects. Waste Management, 52, 286-294.

[15] Capson-Tojo, G., Trably, E., Rouez, M., Crest, M., Steyer, J-P., Delgenès, J-P. and Escudié, R. 2017. Dry anaerobic digestion of food waste and cardboard at different substrate loads, solid contents and co-digestion proportions. Bioresource Technology, 233, 166-175.

[16] Cogan, M. and Antizar-Ladislao, B. 2016. The ability of macroalgae to stabilise and optimise the anaerobic digestion of household food waste. Biomass and Bioenergy, 86, 146-155.
[17] Kang, C. M. 2015. Increased anaerobic production of methane by co-digestion of sludge with microalgal biomass and food waste leachate. Bioresource Technology, 189, 409-412.

[18] Curry, N. and Pillay, P. 2012. Biogas prediction and design of a food waste to energy system for the urban environment. Renewable Energy, 41, 200-209.

[19] Marañón, E. 2012. Co-digestion of cattle manure with food waste and sludge to increase biogas production. Waste Management, 32(10), 1821-1825.

[20] Aichinger, P., Wadhawan, T., Kuprian, M., Higgins, M., Ebner, C., Fimml, C., Murthy, S. and Wett, B. 2015. Synergistic co-digestion of solid-organic-waste and municipal sewage-sludge: 1 plus 1 equals more than 2 in terms of biogas production and solids reduction. Water Research, 87, 416-423.

[21] El-Mashad, H. M. and Zhang, R. 2010. Biogas production from co-digestion of dairy manure and food waste. Bioresource Technology, 101, 4021-4028.

[22] Mousaa, H., Obaidatb, A., Khaledb, H.B., Alawanehb, A. and Tarawneh, A. 2016. Experimental Investigation of Biogas Production from Kitchen Waste Mixed with Chicken Manure. The Journal of Engineering Research, 13(2), 115-123.

[23] Raposo, F., Banks, C. J., Siegert, I., Heaven, S. and Borja, R. 2009. Influence of inoculum to substrate ratio on the biochemical methane potential of maize in batch tests. Process Biochemistry, 41(6), 1444-1450.

[24] Esposito, G., Frunzo, L., Panico, A. and Pirozzi, F. 2012. Enhanced bio-methane production from co-digestion of different organic wastes. Environmental Technology, 33(24), 2733-2740.

[25] Callaghan, F. J., Wase, D.A.J., Thayanithy, K. and Forster, C. F. 1999. Co-digestion of waste organic solids: Batch studies. Bioresource Technology, 67(2), 117-122.

[26] El-Mashad, H. M. and Zhang, R. 2010. Biogas production from co-digestion of dairy manure and food waste. Bioresource Technology, 101(11), 4021-4028.

[27] Zamanzadeh, M., Hagen, L. H., Svensson, K., Linjordet, R. and Horn, S. J. 2017. Biogas production from food waste via co-digestion and digestion- effects on performance and microbial ecology. Scientific Reports, 7(1), 17664.

[28] Zhang, L., Lee, Y.W. and Jahng, D. 2011. Anaerobic codigestion of food waste and piggery wastewater: Focusing on the role of trace elements. Bioresource Technology, 102(8), 5048-5059.

[29] Hegde, S. and Trabold, T. A. 2019. Anaerobic Digestion of Food Waste with Unconventional Co-Substrates for Stable Biogas Production at High Organic Loading Rates. Sustainability, 11(14), 3875. 